\title{
The Impacts Of CEO Turnover \& Degree Of Internationalization On The Accuracy Of Analyst Forecasts
}

Marc R. Bernard, Nova Southeastern University

\begin{abstract}
This study analyzes the impact of CEO turnover on the accuracy of analyst forecasts. Specifically, it examines the level of information that becomes available to analysts covering firms with different levels of internationalization, a proxy for firm complexity, during periods surrounding these events. After controlling for analyst and firm characteristics, along with regulatory period variables, this study finds that the accuracy of analyst forecasts improves in periods immediately following the turnover event. Results further indicate that the accuracy in the post-turnover period is greater for firms with lower levels of internationalization. In general, these findings are consistent with prior research describing the improvement of forecasts surrounding the CEO turnover event, the positive link between forecast accuracy and company disclosures, and finally, the negative link between analyst forecast accuracy and the complexity of the forecasting task.
\end{abstract}

Keywords: CEO, Chief Executive Officer, turnover, turnover event, analyst forecasts, earning forecasts, forecast accuracy, internationalization, degree of internationalization, firm complexity, voluntary turnover, forced turnover, transparency, duality, successor, regulation fair disclosure, Sarbanes-Oxley

\section{Introduction}

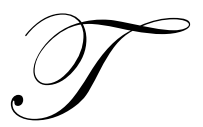

he impact of CEO turnover is a popular topic and has been thoroughly discussed in the literature. Studies have analyzed several perspectives regarding the impact of CEO turnover. In general, there are many reasons why CEOs might depart from their position. Given the circumstance surrounding the event, a certain level of information may be disclosed about the company. Voluntary turnovers usually follow the natural course and limited information typically becomes available. However, when a CEO is forced out of the company, the literature has found that this is often related to negative company performance or other important reasons that the company must divulge to the public while simultaneously terminating the CEO. This information can be used by analysts to provide better post-turnover forecasts when compared with the pre-turnover forecasts. This additional transparency is typically only useful for a limited amount of time while the new CEO becomes acquainted with the firm. After some time, the impacts of the new CEO begin to take affect, and the different management styles begin to diverge, leading to either consistent or different levels of accuracy, depending on the new management team and their relationship with Wall Street. However, as the level of firm complexity increases, the post-turnover information is expected to have a lower impact on forecasts.

This study investigates the impacts of CEO turnover and internationalization on the accuracy of analyst forecasts. There has been limited research in this area, particularly as it relates to the firm's degree of internationalization, herein related to firm complexity. Sheikholeslami, Wilson, and Selin (1998) provided some initial insights and empirical findings to the relationship between CEO turnover and forecast accuracy, but did not incorporate other factors, such as the impact from the firm's degree of internationalization. There exists a vast amount of research linking forecast accuracy and internationalization (e.g., Chansog \& Pantzalis, 2003; Erwin \& Perry, 2000; Clement, 1999; Dunn \& Nathan, 2005; Erwin \& Perry, 2000; Jacob, Lys, \& Neale, 1999). Hence, this study extends the literature by assessing the relationship between CEO turnover and forecast accuracy for different levels of internationalization. 
This paper is structured as follows. This first section provides a review of the literature regarding analyst forecasts, followed by the relevant research associated with the impact of the firm's degree of internationalization, and the impact of CEO turnover. This section leads to the hypothesis development for this study, followed by the research methodology, results and finally, concluding remarks.

\section{Literature Overview}

\subsection{Overview Of Analysts And Their Forecasts}

Analyzing the accuracy of stock analyst earnings forecasts is essential for investors, portfolio managers, executive-management, researchers, etc. The theory surrounding forecasting is known as the information integration hypothesis ${ }^{1}$ in the forecasting literature (Bunn \& Wright, 1991; Sheikholeslami, et al, 1998). Several studies in the literature have focused on different aspects of security analysts and their forecasts. Analysts are considered as important information intermediaries between the companies they cover and investors of interest (Cox \& Kleiman, 2002). Their forecasts are also considered important in maintaining a certain level of efficiency in the capital markets (Herrmann \& Thomas, 2005).

Puffer and Weintrop (1991) stated that financial analyst forecasts are generally regarded as a good proxy for the board of directors' beliefs about the firm's future performance In general, security analysts are considered financial experts, and considered to be the primary gatherers, filters, and interpreters of information from the companies they cover (e.g., Bernard, 2008; Clement, 1999; Hsu \& Chiao, 2006; Mensah, Nguyen, \& Prattipati, 2006). This information is important to build a mosaic of non-material information to derive the best forecasts for the company's earnings and also provide stock price recommendations. Their forecasts are further invaluable since studies have shown the link between analyst forecast accuracy and the analyst's ability to provide profitable stock recommendations (e.g., Loh \& Mian, 2006). Furthermore, the study of market efficiency requires a close analysis of stock analysts (Hsu \& Chiao, 2006).

The literature contains several studies that attempt to analyze the forecasting accuracy of analysts. According to Cox \& Kleiman, early studies (e.g., Brown \& Rozeff, 1980; Butler \& Lang, 1991; O'Brien, 1987 \& 1990) commonly found that analysts could not consistently provide accurate earnings forecasts over time (2002). However, later studies found analysts that could provide better forecasting accuracy than others on a regular basis (e.g., Cox \& Kleiman, 2002; Sinha, Brown, \& Das, 1997). Furthermore, several studies have assessed the analyst's ability to evaluate publicly available information about the firms they cover, and their ability to generate accurate forecast and determine future firm performance (e.g., Clement \& Tse, 2003; Herrmann \& Thomas, 2005; Mikhail \& Willis, 2003). Hence, it is expect that analysts influence market expectations and the prices of the securities they cover (Brockman \& Brooks, 1998; Shekholeslami et al., 1998).

Prior research based on the information integration hypothesis (Bunn \& Wright, 1991) have found that analyst forecasts provide some relevant accuracy using outside information or when their forecasts are compared to time series models (Brown, Griffin, Hagerman, \& Zmijeski, 1987; Sheikholeslami, et al., 1998). Sheikholeslami et al. (1998) analyzed the impact of CEO turnover on the accuracy of financial analysts' earnings forecast and showed that forecasts following the turnover event are marginally more accurate and attributed these findings to the publicity surrounding CEO replacements.

The ability of analysts to improve the accuracy of their forecasts is often based on the complexity of the task at hand. Task complexity has been defined as a combination of task difficulty and task structure (Bonner,

\footnotetext{
${ }^{1}$ Sheikholeslami et al. (1998) described the information integration hypothesis to have an "implication that financial analysts might do better than statistical forecasting techniques because they might be able to integrate outside (i.e., non-time series) information into the forecasting process" (p. 72).
} 
$1994)^{2}$. In separate reviews of the literature on forecasting accuracy, Brown (1993) and Brown, Foster, and Noreen (1985) concluded that complexity of the forecasting task has an impact on the ability to forecast correctly. Furthermore, studies have found that the accuracy of analyst forecasts declines as the complexity of the forecasting task increases (e.g., Bhushan 1989; Brown et al., 1987; Clement, 1999; Duru \& Reeb, 2002; Haw, Jung, \& Ruland, 1994; Lang \& Lundholm, 1996). Other research has provided evidence that the optimistic bias of forecasts is greater for firms with less predictable earnings (e.g., Das, Levine, \& Sivaramakrishnan, 1998; Lim, 2001).

\subsection{Internationalization}

\subsubsection{Introduction}

Many corporations are subjected to the effects of internationalization, and consequently benefit from many new factors, including new markets, investors, suppliers, customers, etc, but must also manage several risks, including currency risk, political risk, regulatory risk, economic risk, sovereign risk, etc. Furthermore, the degree of internationalization of firms has been found to be consistently increasing over time (Denis, Denis, \& Yost, 2002). Firms with operations and sales in international markets also tend to have more complex financial statements than their domestic counterparts. Depending on the location and number of countries or regions in which a given firm has operations, the analysis of the firm's future prospects becomes increasingly difficult. Nonetheless, internationalization provides a level of diversification for a firm's operations and can potentially stabilize earnings.

Several studies have analyzed the impacts of internationalization with different aspects of the firm (e.g., Beim \& Calomiris, 2001; Diamonte, Liew, \& Stevens, 1996; Lang \& Lundholm 1996; Morck \& Yeung, 1991). Also, internationalization has been considered a proxy for task complexity (Khurana, Pereira, \& Raman, 2003). Finkelstein and Hambrick (1989) identified multinational firms as the most complex managerial decision-making environment. Similarly, Duru and Reeb (2002) concluded that the geographic diversity within a firm increases operational flexibility in multinational corporations and allows them to increase value by exploiting the greater uncertainty of the international environment.

According to some findings, international involvement has been found to offer diversification benefits in the form of profit stabilization (Hugues, Logue, \& Sweeney, 1975; Qian, 1996; Reeb, Mansi, \& Allee, 2001; Reuer et al., 2000). Other research has indicated that international diversification leads to lower risk and higher returns (Kim, Hwang, \& Burgers, 1993) due to the increased operational flexibility in a global environment (Dunning \& Rugman, 1985).

\subsubsection{Internationalization And Forecast Accuracy}

Several studies in the international literature have assessed different aspects of analyst forecasts (e.g., Ashbaugh \& Pincus, 2001; Bernard, 2008; Das \& Saudagaran, 1998; Das \& Saudagaran, 2002; Erwin \& Perry, 2000; Hope, 2003; Hope \& Kang, 2005; Lang, Lins, \& Miller, 2003; Riahi-Belkaoui \& Alvertos, 1998). Research has also indicated that the accuracy of forecasts improves when companies disclose more information about their geographic segments (e.g., Balakrishnan, Harris, \& Sen, 1990; Baldwin, 1984; Collins, 1976; Nichols, Tunnel, \& Seipel, 1995; Roberts, 1989). Other findings have found that the amount of international disclosures have an impact on the accuracy of earnings forecasts (Gietzmann \& Trombetta, 2001; Hope, 2003), and that the level of disclosure regulations in foreign countries may impact the degree of accuracy of analyst forecasts for stocks within those countries (Tong, 2007). In general, a higher number of firm segments typically leads to greater firm complexity, and therefore more information must be disclosed and analyzed on a per-segment basis in order to determine overall firm impacts.

\footnotetext{
${ }^{2}$ Task Difficulty (i.e., amount of capacity or mental processing required) is based on definitions provided by Kahneman (1973), and task structure (i.e., level of specification of what is to be done in the task) is based on definitions provided by Simon (1973).
} 
Morck and Yeung (1991) indicated that the more complex the corporation, the more difficult it is for shareholders to monitor management's decisions. They further suggested that firms with multinational components are more complex entities than firms operating within a single country. Chansog and Pantzalis (2003) argued that an increase in a company's degree of organizational complexity and potential for agency conflicts, common among diversified firms, could result in significant errors in analyst forecasts.

Other research examined the impact on analyst forecast accuracy when firms increase their operations globally, including the expansion within their industry and across different industries. Erwin and Perry (2000) found that analyst forecast errors are greater for firms that expand globally and expand across industries, versus those firms that also expand globally, but stay within the same industry. Hence, the total number of industries followed internationally leads to increased complexity and decreased forecast accuracy (e.g., Clement, 1999; Dunn \& Nathan, 2005; Erwin \& Perry, 2000; Jacob et al., 1999).

Ashbaugh \& Pincus (2001) indicated that analysts typically have more information about local and domestic country operations for a given firm and less information about the firm's foreign operations. This problem can ultimately lead to inefficient and inaccurate forecasts, particularly as the percentage of foreign operations increases for the given firm. Duru \& Reeb (2002) provide empirical results suggesting that earnings become more complex as firms become more geographically diversified.

Research by Das and Saudagaran $(1998,2002)$ found that analyst forecasts for non-U.S. firms were less accurate than U.S. firms, and the level of accuracy could be linked to different countries in which covered companies were incorporated. Hope and Kang (2005) indicated that the analyst forecast accuracy of firms with international operations must take in consideration the macroeconomic uncertainty of those countries. Their research suggested that forecast accuracy is inversely related to the level of macroeconomic uncertainty. Research by Forbes, Huijgen, and Plantinga (2006) provided similar results, whereby analysts do not completely take in consideration country and industry specific information into their forecasts.

As described in prior sections, there is an evident link between international earnings forecasts and firm complexity. Khurana, Pereira, and Raman (2003) found that analysts do not take into consideration the persistence of foreign earnings. They further indicated that the information flow between these organizations, analysts, and investors was sub-optimal and contributed to mispricings in earnings for U.S. companies.

In summary, the literature has shown that analysts must consider several factors when analyzing companies with various degrees of internationalization. It is necessary, but often difficult to assess the impact of each segment within many firms. Hence, an increase in the degree of internalization has been found to have an impact on the complexity of the company, ultimately resulting in a decreased level of accuracy of their earnings forecasts.

\subsection{CEO Turnover}

\subsubsection{Introduction}

The replacement of top executives is one of the most important decisions made by a company's board of directors (e.g., Fama \& Jensen, 1983; Hillier, Mashall, McColgan, \& Werema, 2006). Furthermore, although one of the most important concerns for incumbent top management is job security (Huang \& Yen, 1996), the average CEO tenure is gradually decreasing and CEO turnover is gradually increasing within US companies (Lucier, Spiegel, \& Schuyt, 2002; Radler, 2003). Sheikholeslami et al. (1998) referred to the CEO turnover event being related to an attention directing hypothesis. This paper ultimately extends prior research on this topic.

Changes in CEO turnover have been astonishing in recent years. According to a Booz Allen Hamilton (BAH) study, the mean tenure for a CEO dropped from 9.5 year in 1995 to 7.3 years in 2001. The study indicated that CEOs are also getting younger, and the tenure was expected to continue decreasing over time (Lucier, Spiegel, \& Schuyt, 2002; Radler, 2003). A more recent BAH study (e.g., Fifth annual survey of CEO turnover from the 
world's 2,500 largest publicly traded corporations) indicated that European and North American CEOs had the greatest number of involuntary, also known as forced turnovers (Paladino, 2007).

The percentage of forced turnovers has also increased over time. Stewart (2007) indicated that someone working for an American company will have a 50\% chance of working for a new CEO within four years. The average tenure for a CEO ranges between approximately 18 to 24 months and $55 \%$ of global firms do not have an adequate succession plan when CEOs leave (Kelly, 2007). This prior research also indicated that the first 90 days of a new CEO's tenure is a honeymoon period, also known as the exploration stage, where CEO become acquainted with the company. The next thirteen-to-fourteen months are the building stage, and the contributing stage is beyond fourteen months, where CEOs are expected to provide results for shareholders.

Gaines-Ross (2002) examined results of a 2001 study by Burson-Marsteller ("Building CEO Capital ${ }^{\mathrm{TM}}$ ") and provided several perspectives from different groups regarding the reasons why CEOs fail ${ }^{3}$. In this survey, CEO's and top executives responded that the lack of a strategic vision and the lack of effective execution were the top two reasons why CEOs fail. Financial analysts were also given this survey, and indicated that CEO failure was caused by a lack of effective execution and by lost credibility within their firms and with company stakeholders. These results indicate that if CEOs are unable to motivate their employees and if they are unable to execute their desired plans and/or strategies, their firms will not perform as expected by the investment community. Consequently, the firm's operating results may not fall in-line with analyst estimates, which can be disastrous for the CEOs' reputation and credibility. The following section discusses relevant literature findings regarding the impacts of CEO turnover.

\subsubsection{Some Relevant Studies}

The level of CEO turnover often remains constant in many scenarios. A study by Hadlock, Lee, and Parrino (2002) compared CEOs from regulated and unregulated companies and found no difference in the average level of CEO turnover between the two, suggesting that CEOs from both groups stay in office equally long. Their study did find that CEOs from unregulated firms are more likely to be forced out and replaced by an outside executive. Next, according to 2001 data from Bernstein (2006), the level of CEO turnover remained constant regardless of the financial distress regimes of the given companies. This study further suggested that a CEO gets all the credit when a company does well, but when performance lacks, the CEO is usually blamed and often ousted as a result.

Persons (2006) indicated that firms involved with fraud or lawsuit situations, as reported by the WSJ, had larger occasions of CEO turnover than similar firms that were not engaged in such situations. Their study also indicated that CEOs holding the position of chairman of the board were less likely to be terminated than CEOs not having both positions. These findings indicated that the revelation of negative information can increase the probability of a CEO turnover event, but it also revealed that public announcements provide additional information about the company, leading to an increased level of transparency of the firm's financial condition. Hence, after the information is revealed to the public, private information now becomes public and provides an additional layer of transparency regarding the firm's internal situation, which can lead to improved forecasts around a CEO turnover event, at least for a certain amount of time until the new CEO becomes entrenched and begins engaging in the job self-preservation behavior (Huang \& Yen, 1996).

There are many popular examples where CEOs were removed from office, such as the case in the early 2000's when Enron, Global Crossing, and WorldCom all replaced their CEOs after revealing their fraudulent financial reporting (Persons, 2006). More recently, several CEOs were ousted while their employers simultaneously revealed massive losses due to the sub-prime mortgage markets. For example, UBS fired CEO Peter Wuffli in July

\footnotetext{
${ }^{3}$ In this survey, different groups were asked to provide their opinion from the following items as to why CEOs fail: Lack of strategic vision, does not execute well, loss of credibility, poor earnings, failure to adapt to change, poor match with company culture. Groups queried include CEOs, top executives, financial analysts, media, and government.
} 
2007, Stan O'Neal was fired as the CEO of Merrill Lynch \& Co in October 2007, and Citigroup's CEO Charles Prince was fired in November 2007.

\subsubsection{CEO Turnover \& Operating Performance}

Prior literature has found that CEO turnover events are likely to cause a firm to undergo changes in strategic orientation compared to other firms that did not face such a CEO turnover event (Haddadj, 1999; Wen, 2005). Several studies have also found that CEOs were forced out after prolonged periods of poor performance relative to industry and market benchmarks (e.g., Conyon \& Florou, 2002; Coughlin \& Schmidt, 1985; Dedman \& Lin, 2002; Harrison, Torres, \& Kukalis, 1988; Hillier et al., 2006; Jensen \& Murphy. 1990; Parrino, 1997; Warner Watts, \& Wruck, 1988; Weisbach, 1988; Worrell, Davidson, \& Bland, 1999), and that the probability of CEO turnover increases as firm performance decreases (Lucier et al., 2002; Wen, 2005).

According to the literature, there is a statistically significant inverse relationship between CEO turnover and accounting performance benchmarks, such as EPS, FCF, EBIT/Assets (Newmann \& Voetmann, 2005; Huson, Parrino, \& Starks, 2001). In particular, Hillier et al. (2006) found that the performance of firms that experience CEO turnover begins to deteriorate from an operating performance and financial leverage perspective up to three years prior to the turnover event. According to Abdelgany (2005), earnings management usually occurs around the time of management changes, thus the CEO of a company with poor performance indicators will try to increase the reported earnings in order to prevent or postpone being fired.

\subsubsection{Post-Turnover Event Data}

The literature has indicated that changes in accounting policies have led to improved operational performance after a CEO turnover event (Denis and Denis, 1995; Neumann \& Voetmann, 2005). Similarly, according to Hillier et al. (2006), there is a general assumption that a fired CEO is the primary cause of the firm's misfortunes and that a new CEO will lead the company to a brighter future. The CEO turnover aftermath performance has been identified as the improved management hypothesis (Huson, Malatesta, \& Parrino, 2004).

Consistent with the improved management hypothesis from Huson et al. (2004), Hillier et al. (2006) found that performance improved after a forced turnover event and that a large amount of new negative information was released around the CEO dismissal announcement. Along with this negative information, Murphy and Zimmerman (1993) indicated that company return-on-assets (ROA) decrease after a turnover event and also provided an "earnings bath" reasoning to the decline in ROA, which would allow the new management team to reduce earnings to a point that allowed their future performance to seem successful. Although news was negative in these circumstances, it allowed management to realign the company's realistic situation with the market. This new information is negative but improves transparency within the company and should provide analysts additional information, allowing them to issue improved forecasts during periods following the turnover event. Since prior studies did not find this type of information release during voluntary turnover events, the improved transparency is expected to have a greater impact on forecast accuracy for forced turnovers events than for voluntary turnover events.

It is important to note that many studies observed operating performance improvements after a forced and a voluntary turnover (e.g., Denis \& Denis, 1995; Huson et al., 2004; Kang \& Shivdasani, 1995), and that other studies provided mixed results, indicating that performance did not necessarily improve immediately after the turnover event occurred (Dahya et al., 1998; Dedman \& Lin, 2002). The general idea surrounding these studies indicates that a company will typically invoke a change in CEO following periods of poor performance, and often take the turnover event to publicly realign the company's financial situation with the investment public. This realignment often results in the announcement of negative information.

Several studies provided evidence explaining how CEOs can make a difference. Some studies related performance of the firm following the turnover event to the quality of the CEO (e.g., Hillier et al, 2006; Khanna \& Poulsen, 1995). Several other findings indicated that the financial performance improves after the CEO turnover 
occurs (e.g., Wen, 2005). This phenomenon may be coincidental with the fact that the firm has likely issued news about the company's actual financial condition, ultimately driving down the stock price and increasing various risks. Thus, when the new CEO takes over, the company may find itself in an abnormally low position and has a greater potential to increase its performance from the current, unfounded levels.

The average and median industry-adjusted return on total assets (ROA) has been found to increase over periods starting one year before and ending two or three years after CEO turnover (Denis \& Denis, 1995). Other studies have provided a different perspective on the extent in which the new CEO or the previous CEO impacts the performance of a company (e.g., Hillier et al., 2006; Huson et al., 2004; Khanna \& Poulsen, 1995). The literature has even discussed the concept of a scapegoat hypothesis, whereby the CEO is used as a scapegoat for operating performance, even though the poor performance may actually be related to different issues out of their control (Hillier et al., 2006).

Wen (2005) discussed additional CEO turnover theories from the literature. The first theory mentioned how boards select new CEO successors to create change within the firm's existing internal environment, as it relates to employees and executives, or the firm's external environment, as it relates to investors and the stock market. Prior studies also provided evidence that CEOs tend to reverse decisions made from prior executives (Weisback, 1995; Wen, 2005). Ultimately, the actions of the board and the new executives reflect a theory that emphasizes the new leader's ability to improve the firm's financial stability and shareholder wealth (e.g., Rowe \& Davidson, 2000; Wen, 2005). However, Wen (2005) examined another theory from prior studies (e.g., Khanna \& Poulsen, 1995; Warner et al., 1988; Weisbach, 1988), which assumed that the CEO does not directly have any impact on firm performance ${ }^{4}$. Overall, there may be a conflict in the literature regarding the expected performance of the firm in the post-turnover period, but there is no doubt that the amount of information that becomes publicly available tends to increase.

\subsubsection{Turnover \& Successor Classification}

There are many reasons why CEOs leave their post within a company. In general, the departure can be voluntary or non-voluntary. According to the literature, a potential bias in the data can exist when comparing company performance with executive turnover and turnover classification is not identified (Voetmann \& Newmann, 2005; Warner et al., 1988). Hillier et al. (2006) qualify a turnover as forced when the CEO has been "fired, forced out, left following policy disagreements, boardroom shake-ups, poor performance, outside pressure or some other equivalent" (p. 7). In their study, a turnover was equally classified as forced when the CEO was under the age of 60, and the announcement did not explain the reason for their departure as being related to health or if the CEO accepted a different position. All other turnover announcements were classified as voluntary. Similarly, Denis, Denis, and Sarin (1997) classified non-routine top executive changes (i.e., forced turnover) as all top executives changes except those related to death, illness and retirement.

Neumann \& Voetmann (2005) indicated that there is "no obvious method to classify a resignation as forced if the press release or the report from Reuters Business Briefing does not include this information". They further presented criteria to identify a forced turnover: "(1) announcements of sudden resignations in which a CEO left the firm immediately and does not leave for other employment, (2) mutual agreements between the CEO and the board of directors, (3) organizational changes such as divestments or a merger that leads to a turnover" (p. 29).

Blackwell and Dudney (2007) followed a similar CEO turnover classification as prior important studies (Gilson, 1989; Weisback, 1988; Parrino, 1997). A turnover was considered as forced in all "CEO changes other than those from retirement, normal management succession, death, illness, or those involving the CEO's departure for a prestigious position elsewhere" (p. 319). Voluntary retirement was associated with any CEO that was 64 year of age

\footnotetext{
${ }^{4}$ Wiersema (2002) examined company performance two years before and two years after CEO turnover and found that companies with CEO turnovers experienced no significant improvement in their operating earnings or their stock performance.
} 
or older unless otherwise stated as being performance related. In their overall sample of 121 firms involving turnovers during the 1981-1992 timeframe, $76 \%$ were voluntary turnovers and 24\% were forced ${ }^{5}$.

According to Clayton, Hartzell, and Rosenberg (2005), CEO change decisions are based on the board's desire to continue the company's existing strategy via an internal successor or to move with a different strategy via an external successor. Worrell, Davidson, and Glascock (1993) examined the firings of key executives and regard the replacement of an executive by an outsider as beneficial whereas the replacement by an insider is often associated with less certainty about the successor's capabilities.

\subsubsection{CEO Turnover And Forecast Accuracy}

A study by Sheikholeslami et al. (1998) investigated the impacts of analyst forecast accuracy surrounding CEO turnover events and indicated that "CEO turnover could affect earnings predictability for at least two reasons. One reason is that CEO changes may cause operational ("real") changes in earnings stream. Another reason is that CEO changes may lead to accounting ("cosmetic") changes" (p. 72). They compared a group of firms that experienced management turnover with a control group of firms that did not experience turnover, and found that firms with CEO turnover events are associated with more accurate forecasts in the post event period than in the preevent period. This study extends prior research by examining how the information that becomes available around a CEO turnover event would impact analyst forecasts for firms with different levels of internationalization, a proxy for complexity.

\section{Hypothesis Development}

The literature has shown that the level of information disclosed during the periods leading to and following a CEO turnover event can provide additional level of transparency that will allow analysts to provide better forecasts in the post-turnover period. However, given that this information is revealed during the turnover event, the transparency is expected to degrade during the period leading to this event, ultimately leading to an incremental negative impact on the accuracy of analyst forecasts during the pre-turnover periods. Hence, after taking in consideration the relevant control variables, the following hypotheses take in consideration the impacts of the CEO turnover event on the accuracy of analyst forecasts during pre-turnover and post-turnover periods.

H1: Ho (null): CEO turnover events do not have a negative impact on analyst forecasting accuracy during pre-turnover periods.

Ha (alternative): CEO turnover events have a negative impact on analyst forecasting accuracy during pre-turnover periods..

H2: Ho (null): CEO turnover events do not have a positive impact on analyst forecasting accuracy during post-turnover periods.

Ha (alternative): CEO turnover events have a positive impact on analyst forecasting accuracy during post-turnover periods.

Again, the literature has shown that the accuracy of analyst forecasts decreases as the level of complexity of the forecasting task increases. The literature has further indicated on many occasions that the firm's degree of internationalization can be considered as a proxy for the level of complexity of the firm. On a similar note, it has equally been found that the degree of internationalization tends to provide a greater level of diversification for earnings, which tends to stabilize the volatility of earnings. It is therefore expected that the level of complexity will first have an impact on the new CEO's ability to immediately contribute to firm performance in the post turnover event. The increase in firm complexity is also expected to have an impact on the analysts' ability to provide better forecasts in the post-turnover periods, even when additional information about the company becomes public. Hence,

\footnotetext{
${ }^{5}$ Other studies found that the percentage of forced CEO turnovers ranged from $14 \%$ to $17 \%$. (i.e., Clayton, Hartzell, \& Rosenberg, 2005; Denis \& Denis, 1995; Mehran and Yermack, 1997).
} 
after taking in consideration the relevant control variables, the following hypotheses take in consideration the impacts of internationalization on the accuracy of analyst forecasts before and after the CEO turnover event.

H3: Ho (null): A higher degree of internationalization in the covered stock does not lead to a decrease in the accuracy of analyst forecasts during pre-turnover periods.

Ha (alternative): A higher degree of internationalization in the covered stock leads to a decrease in the accuracy of analyst forecasts during pre-turnover periods.

H4: Ho (null): A higher degree of internationalization in the covered stock does not lead to a decrease in the accuracy of analyst forecasts during post-turnover periods.

Ha (alternative): A higher degree of internationalization in the covered stock leads to a decrease in the accuracy of analyst forecasts during post-turnover periods.

\section{Research Methodology}

The following section provides a description of the dependent and independent variables to be examined, followed by an overview of the regression model used to analyze the hypotheses.

\subsection{Dependent Variables, Absolute Forecast Error}

The accuracy of analyst forecasts is inversely related to the forecast error. The dependent variables used to analyze forecast error are (a) the natural logarithm of the mean absolute forecast error, LnMAFE $E_{j, t}$, and (b) the natural logarithm of the normalized mean absolute forecast error, $L n N A F E_{j, t}$ for a given company (j) during a given period (t). These variables are influenced by recent studies (e.g., Brown, 2001; Clement, 1999; Fortin \& Michelson, 2006; Sheikholeslami et al., 1998 $)^{6}$. First, the model for the mean absolute forecast error $\left(M A F E_{j, t}\right)$ is provided below:

$M A F E_{\mathrm{j}, \mathrm{t}}=\frac{\sum_{i=1}^{M} A F E_{i, j, t}}{M}$

In this model, $A F E_{i, j, t}$ is defined as the absolute forecast error for a given analyst (i)'s forecast of firm $(j)$ during a specified period $(t)$ and $M$ is the total number of analysts making forecasts for firm $(j)$ during period $(t)$. Each value of $A F E_{i, j, t}$ is calculated as the absolute difference between the actual earnings for firm $(j)$ during period $(t)$ and the last forecast made by each analyst $(i)$. Next, the normalized absolute forecast error, $N A F E_{j, t}$, is calculated as the absolute value of $M A F E_{j, t}$ divided by the actual earnings for firm (j) during period ( $\left.\mathrm{t}\right)^{7}$. This study assesses the natural logarithm of both variables to ensure that any non-linear effects are minimized.

\subsection{Independent Variables}

The following section provides a summary of the independent variables.

\footnotetext{
${ }^{6}$ The variables used for forecast error in this study vary slight from that used from Shek (1998). Additional regressions were performed using the prior variable used by Sheikholeslami et al., (1998), but the regressions were found to have positive autocorrelation, hence, results were not considered reliable for inclusion in this study.

${ }^{7}$ EPS is not included as an independent variable since the normalized lagged AFE takes this factor in consideration. Separate tests not discussed in this study have shown that EPS is not a significant variable in regressions for (a) LnMAFE. EPS was also found to have a high correlation with (b) LnNAFE ( $>0.35$ ), hence, to minimize the effect of multicolinearity, this parameter was omitted from further analysis in this study.
} 


\subsubsection{Turnover Classification}

The turnover classification is associated with two dummy variables, VOLUNTARY $Y_{\mathrm{j}, \mathrm{t}}$ and FORCED $_{\mathrm{j}, \mathrm{t}}$. These variables are set to one for up to four quarterly periods ( $t$ ) following the applicable turnover event for a given firm (j). Given their impact in prior studies and their relevance to this study, they are used utilized as control variables. The post-turnover period a selection criterion is defined below.

\subsubsection{Duality Classification}

Duality has been an important variable in the literature (e.g., Brickley, Coles, Jarrell, 1997; Dahya et al., 2002; Hillier et al., 2006; Neumann \& Voetmann, 2005). This study incorporates DUALITY, $\mathrm{j}_{\mathrm{j}, \mathrm{t}}$ as a control variable in assessing the accuracy of analyst forecasts for firm (j) during each period (t). This variable is set to one for all applicable duality periods before or after the turnover event.

\subsubsection{Successor Classification}

The successor classification variables, EXTERNAL $\mathrm{j}_{\mathrm{j}, \mathrm{t}}$ and INTERNAL $_{\mathrm{j}, \mathrm{t}}$ are based on the board's decision to hire an internal successor or an external successor as CEO. Given the research on successors (e.g., Worrell et al., 1993), this study incorporates the successor classification as control variables in the model. The first dummy variable, EXTERNAL $\mathrm{j}_{\mathrm{j}, \text {, }}$ is set to one for up to four quarters in a post turnover period involving an external successor. Similarly, the second dummy variable, INTERNAL $\mathrm{j}_{\mathrm{j}, \mathrm{t}}$ is set to one for up to four quarters in a post turnover period involving an external successor. The post-turnover period a selection criterion is defined below.

\subsubsection{Degree Of Internationalization}

Many studies in the literature have used different methods to measure the firm's level of DOI. This study uses a similar methodology followed by Duru and Reeb (2002) to assess the DOI of a given firm (j) during a given period (t). This method first constructs a composite measure of DOIj,t for all sample firms. This measure is determined by applying factor analysis to combine three primary measures (i.e., foreign sales ratio (FSRj, $\mathrm{t}$ ), foreign asset ratio (FARj,t), and the number of geographic segments (GEOj,t)) into a single index. The following equation summarizes analysis of the $\mathrm{DOIj}, \mathrm{t}$ variable:

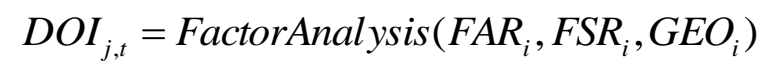

Where:

$F S R_{j, t}:$ Total foreign sales for firm ( $\left.j\right)$ during period $(t)$ divided by total sales by firm $(j)$ during period $(t)$.

$F A R_{j, t}:$ Total foreign assets for firm $(j)$ during period $(t)$ divided by total assets by firm $(j)$ during period $(t)$.

$G E O_{j, t}:$ Total number of countries in which firm $(j)$ had operating segments during period $(t)$.

This study further assesses the natural $\log$ of $D O I_{j, t}$ to ensure that any non-linear effects in this independent variable are minimized. $\mathrm{Ln} D O I_{j, t}$ is initially used as an independent control variable in the multiple regression model for the first hypothesis. This study further extends the use of $\operatorname{Ln}_{D O I} I_{j, t}$ as a control variable to further improve the multiple regression results and analysis for $\mathrm{H} 3$ and $\mathrm{H} 4$. Hence, this variable is also used to categorize the sample set into two categories to provide a better assessment of the impact of the CEO turnover event on the accuracy of analyst forecasts. These categories included a low DOI category and a high DOI category. Each firm (j) is classified into one of these two categories during each period (t). Each firm is assigned to the low DOI category if the $\mathrm{LnDOI}_{\mathrm{j}, \mathrm{t}}$ for that period is less than the median firm $\operatorname{Ln} D O I_{\mathrm{j}, \mathrm{t}}$ for that period, otherwise the firm is assigned to the high DOI category for the given period.

\subsubsection{Lagged Absolute Forecast Error}

Prior studies have indicated that models assessing past forecast accuracy can provide similar results to other models that incorporate different analyst characteristics (Brown, 2001). This study controls for analyst characteristics by considering the forecast error from the previous period $(\mathrm{t}-1)$ as a predictor for the forecast error in 
the current period ( $t$ ) for a given firm (j). Given that this study examines two dependent variables, the same forecast error variable format used as the dependent variable is used as the independent variable for lagged absolute forecast error.

\subsubsection{Regulation Fair Disclosure And Sarbanes-Oxley Act}

The literature has found that recent legislative events have impacted the accuracy of analyst forecasts (e.g., Bailey et al., 2003; Findlay \& Mathew, 2006; Gomes, Gorton, \& Madureira, 2004; Koh, Matsumoto, Rajgopal, 2005; Kwag \& Small, 2007) as well as the level of transparency of public firms (Aggarwal, 2006; Parsons, 2005). As it relates to the timelines of this study (i.e., 1998-2005), these events include Regulation Fair Disclosure and the Sarbanes-Oxley act of 2002 .

In order to assess RegFD and SOX, this study examines three categories of data associated with each period $(\mathrm{t})$. The first category, PREREGFD, is associated with the pre-RegFD period, prior to October 23, 2000. The second category, REGFD, is associated with the period between October 23, 2000 and July 30, 2002. The third category, SOX, is associated with the period after July 30, 2002. The regression model therefore includes two of the three possible categories as dummy control variables for the regression model. The selected dummy variables are $R E G F_{j, t}$ and $S O X_{j, t}$. Hence, when $S O X_{j, t}$ and $R E G F D_{j, t}$ are zero, the sample observation is considered to be in the PREREGFD period. The dummy variable $R E G F D_{j, t}$ is set to one for all periods between Q3, 2000 and Q2, 2002, inclusive. Similarly, the dummy variable $S O X_{j, t}$ is set to one for all periods between Q3, 2002 and Q4, 2005, inclusive.

\subsubsection{CEO Age}

Prior studies associate the age of the CEO within their selection of the forced versus voluntary variables (e.g., Neumann \& Voetmann, 2005; Hillier et al., 2006). However, given that the average age and tenure of CEOs have been decreasing over time (Lucier, Spiegel, \& Schuyt, 2002; Radler, 2003), this study includes a control variable, $\mathrm{AGE}_{\mathrm{i}, \mathrm{t}}$, for the age of the $\mathrm{CEO}$, but does not expect a significant impact from this variable.

\subsubsection{Number Of Analysts}

The number of analysts covering a given stock has been shown to impact the forecast accuracy (e.g., Irani \& Karamanou, 2003; Lang \& Lundholm, 1996). This study controls for the number of analysts covering firm (j) in a given period (t). This variable is $\mathrm{NUM}_{\mathrm{j}, \mathrm{t}}$.

\subsubsection{Post-Turnover And Pre-Turnover Periods}

Several studies in the literature have examined various timelines before and after the CEO turnover event. Kelly (2007) indicated that the CEO has different integration phases in the post-turnover period, ranging from the first 90 day honeymoon period, to the building stage, and finally the contribution states. Other studies analyze different periods surrounding the turnover event, ranging from quarters to years surrounding the event (e.g., Denis \& Denis, 1995; Hillier et al., 2006).

A relevant study on analyst forecast accuracy should take in consideration the transitional time for the new CEO to be capable of getting acquainted with the firm before making new decisions. Thus, several quarters may be required for the new CEOs to establish themselves, although studies have shown that the patience of investors is decreasing and CEOs are expected to provide results sooner.

Given the differences in prior approaches, this study assesses the impacts of forecast accuracy in different periods following the turnover event. Specifically, the first four quarters in the post-turnover period. Hence, four dummy variables, POST1 $1_{\mathrm{j}, \mathrm{t}}, P O S T 2_{\mathrm{j}, \mathrm{t}}, \operatorname{POST}_{\mathrm{j}, \mathrm{t}}$, and POST4 $4_{\mathrm{j}, \mathrm{t}}$, are associated with the four quarters following the turnover event. After controlling for all factors specified above, these variables shall indicate if the forecasting accuracy increases or decreases in the periods following the turnover event. Hence, to reject the null hypothesis for 
$\mathrm{H} 2$, this study requires that at least one of these variables will be negative and significant after controlling for other relevant variables, and therefore lead to an increase in forecast accuracy during the post-turnover period when assessing the entire sample. Using the same approach, in order to reject the null hypothesis for $\mathrm{H} 4$, this study requires that the forecast accuracy following the turnover event will be lower for firms in the high DOI category than for firms in the low DOI category.

Additional variables are provided to analyze the periods leading up to the turnover period. During these periods, the amount of data communicated to the investment community may be limited or different and therefore must be considered. This study provides a consistent approach between the pre-turnover period variables and the post turnover periods. Hence, four dummy variables, $P R E 1_{\mathrm{j}, t}, P R E 2_{\mathrm{j}, \mathrm{t}}, P R E 3_{\mathrm{j}, \mathrm{t}}$, and $P R E 4_{\mathrm{j}, \mathrm{t}}$, are associated with the four quarters preceding the turnover event quarter. Hence, to reject the null hypothesis for H1, this study requires that one or more of these variables will be positive and significant after controlling for other relevant variables, and therefore lead to a decrease in forecast accuracy during the pre-turnover period when assessing the entire sample. Using the same approach, in order to reject the null hypothesis for $\mathrm{H} 3$, this study expects that the forecast accuracy during the pre-turnover periods will be lower for firms in the high DOI category than for firms in the low DOI category.

\subsection{Model Overview}

The following model is used to test the hypotheses using the variables presented in the prior section. In particular, this equation assesses the impacts of the CEO turnover event on the forecast accuracy of all analysts covering firm $(\mathrm{j})$ during period $(\mathrm{t})$ : 
Table 1

Regression Model

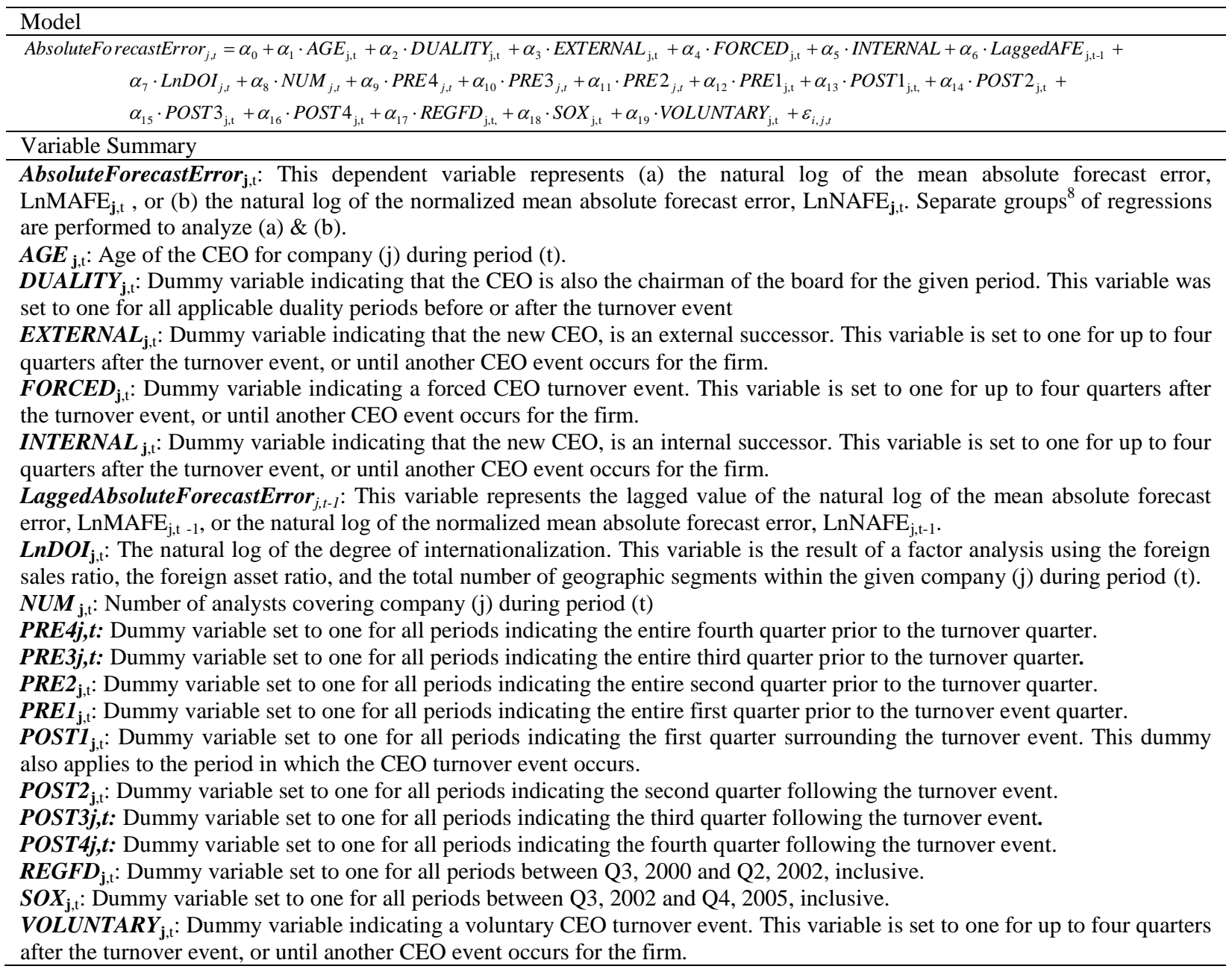

\section{Results}

This section provides an overview of the sample data collected and further examines the validity of the hypotheses. This first section describes the data selection process for the firms, CEOs and analysts, along with the timelines for the study. The next section presents the relevant regression results.

\subsection{Data Collection}

\subsubsection{Firm data}

This study analyzes quarterly data for the period between January 1, 1998 and December 31, 2005. The initial group of firms was based on the S\&P500. All financial data was collected from the Compustat database, ${ }^{9}$ the

\footnotetext{
${ }^{8}$ For each dependent variable, this study performs three regressions: (1) Entire Sample, (2) Low DOI firms only, \& (3) High DOI firms only.
} 
Institutional Brokers' Estimate System (IBES) database, and the ExecuComp database. Consistent with Duru and Reeb (2002), this study omitted all firms that did not report foreign segments and foreign sales in the Compustat Segment database. This first criterion was used to determine the number of SIC codes outside the primary industry. The study then omitted companies that were not part of the S\&P500 constituent list for the entire period. Next, all companies that were not simultaneously present in the Compustat database and in the IBES database (i.e., the database containing analysts' forecast data) were omitted. Companies that did not have fiscal years ending in December were also omitted. Due to the information sensitive nature of this study, and all recent disclosure-related regulations, this study only included companies incorporated in the U.S. Due to their unique disclosure requirements and consistent with prior approaches (e.g., Teoh, Welch, \& Wong, 1998), this study did not include firms from banking and utilities industries. This exercise resulted in an initial sample of $228 \mathrm{firms}$, which were used to calculate the DOI values of all firms using factor analysis ${ }^{10}$.

The resulting DOI factor analysis output produced a single index value for each period. Results indicated that $68 \%$ of the changes in the values of the index were explained by changes in FSR, $23 \%$ of the changes in the value of the index were explained by changes in FAR, and finally, 9\% of the changes were explained by GEO. Results were similar with values produced by Duru and Reeb (2002). The high DOI and low DOI category threshold was determined using the median DOI value of this first group of 228 firms. In assessing each group, the mean values for each of the three factors making up the DOI variable (i.e., factor analysis index) were greater in the high DOI group than in the low DOI group, as expected. For the low DOI group (vs. the high DOI group), the mean value for FAR was $1.41 \%$ (vs. 16.29\%), the mean value for FSR was 6.49\% (vs. 53.77\%), and the value for GEO was 1.83 (vs. 5.20).

\subsubsection{CEO Data}

The next step focused on assigning values to the following variables FORCED, VOLUNTARY, DUALITY, INTERNAL and EXTERNAL. For each of the 228 firms, this study examined CEO data provided in ExecuComp. Turnover events were analyzed by observing the CEOs in the database for each period, and validating turnover with news reported by the company in reputable sources such as the Wall Street Journal and Financial Times. Next, it was necessary to determine if the turnover event was classified as forced or voluntary. ExecuComp's executive compensation survey provided the circumstances of the CEO's departure (e.g., retired, resigned, deceased) and this data was further cross-checked against credible news reports about the company. This study followed the same turnover assignment criteria by Blackwell and Dudney (2007), to identify forced and voluntary turnovers. From the initial group of 228 firms, the final group only considered firms with turnover events during the period under study, resulting in a final sample of 167 companies that experienced 222 turnovers during the 8 year period. In all, 157 $(70.72 \%)$ of the turnovers were considered voluntary turnovers, and $65(29.28 \%)$ were considered forced ${ }^{11}$. When comparing the DOI categories, there were a larger percentage of forced turnovers in the high DOI category than in the low DOI category (i.e., $32.31 \%$ vs. $24.49 \%$, respectively).

The successor information was determined by analyzing news reports specifying whether the new CEO was an existing employee or not. In all, $172(77.48 \%)$ of the turnovers were considered internal turnovers, and 50 $(22.52 \%)$ were considered external turnovers. Again, when comparing DOI categories, the percentage of external turnovers was approximately the same for high DOI and low DOI firms (i.e., $23.08 \%$ vs. $22.45 \%$, respectively).

The duality variable was also determined by the ExecuComp database. Duality was considered for all Topexecutives ranked as both as CEO and chairman of the board for a given period. All other combinations of CEO and

\footnotetext{
${ }^{9}$ The financial data included total sales, total assets, segment sales, segment assets, primary SIC codes, secondary SIC codes, number of foreign segments, and finally number of domestic segments.

${ }^{10}$ The correlation between the three variables varied from 35\% (FAR vs GEO), 49\% (FSR vs GEO), and 70\% (FSR vs FAR). The resulting DOI factor analysis output produced a single set of values for each period, 68\% of which were explained by FSR, $23 \%$ of which were explained by FAR, and $9 \%$ of which were explained by GEO. Results were consistent with values produced by Duru and Reeb (2002).

${ }^{11}$ These results are consistent with similar numbers found by Blackwell and Dudney (2007).
} 
other positions were not considered duality positions. This variable was administered as a control variable for all periods, including pre-turnover and post-turnover periods. In all, 4,030 of a total of 5,179 firm-quarters (i.e., $77.81 \%$ ) were considered duality periods. The duality data in the pre-turnover period accounted for $88.15 \%$ of the firms-periods, and in the post-turnover period, duality accounted for $69.59 \%$ of the firm-periods. Thus, data shows that a duality role in the pre-turnover period does not necessarily lead to a duality role in the post period. Data has shown that in many planned succession cases, the chairman of the board relinquishes the role of CEO to another individual and eventually passes on the board chairman position over time. When comparing the different DOI categories, low DOI firms have a higher duality percentage than high DOI firms during the post-turnover period ( $70.93 \%$ vs. $68.52 \%$, respectively), and also during the pre-turnover period $(90.74 \%$ vs. $85.98 \%$, respectively). Hence, compared to high DOI firms, results indicate that domestically oriented firms are more likely to assign both roles of CEO and chairman of the board to the same person.

The average CEO age for the entire sample was 56.4 years standard deviation of 6.8. The average preturnover CEO age was 59.5 and the average post turnover age was 54.0. However, results differed when considering the turnover conditions and the DOI criteria. The average age was greater for high DOI firm than low DOI firms in the pre-turnover period (60.3 vs. 58.4, respectively), and this difference was significant to the $1 \%$ level. In the post-turnover period, the average age for both high DOI and low DOI firms was statistically indifferent from 54.0.

\subsubsection{Analyst Data}

Next, the following section describes the data selection process for analysts. All data for this part of the study was obtained from IBES, and included all analyst earnings forecasts ${ }^{12}$, forecast dates, and actual earnings for all 167 firms described above. This study further limited the analysis to analysts affiliated with U.S. firms. A total of 3,878 U.S. based analysts and a total of 79,456 forecasts were examined during the entire period ${ }^{13}$. On average, 15.0 analysts analyzed a given company during a given period ${ }^{14}$. The mean number of analysts differed in different categories, including pre-turnover group (14.3) versus post-turnover group (15.6) and low DOI category (13.7) versus the high DOI category (16.2). A greater difference was evident when comparing the two DOI categories. Results for low DOI firms indicated than the average number of analysts increased from 12.5 in the pre-turnover period to an average of 14.6 in the post turnover period. Results for the high DOI firms indicate that the number of analysts increased from 15.7 in the pre-turnover period to 16.5 in the post turnover period. Thus, there is a noticeable increase in the number of analysts covering low DOI firms in the post-turnover period. In all cases, there was a large increase in the average number of analysts covering firms in the quarters leading up to the turnover period, and the number slightly dropped in the quarter surrounding the turnover but continued to increases in subsequent periods.

\subsection{Summary Statistics}

This section provides summary statistics for the final group of firms and analysts. The following table provides a summary of the three groups considered. The first group includes 5,179 firm-quarters. The second group assessed 2,364 quarters (45.6\% of the total) for firms within the low DOI category. Finally, the third group assessed 2,815 quarters ( $54.4 \%$ of the total) for firms within the high DOI category. The larger sample size in the high DOI category indicates that a larger number of non-turnover firms were considered low-DOI firms in the initial group of 228 firms, and therefore not included in the final group of 167 firms.

\footnotetext{
${ }^{12}$ As described in the description of the dependent variable, only the last forecast was kept for each analyst during all given periods.

${ }_{13}$ This number includes 3,241 forecasts from Q4/1997, which were necessary to assess the lagged forecast accuracy in Q1/2008.

${ }^{14}$ The standard deviation for number of analysts covering a company was 8.11 . The minimum number of was 1 , and the maximum was 54 .
} 
Table 2

Descriptive Statistics - Entire Sample, Low DOI sample, and High DOI sample (1998-2005)

\begin{tabular}{|c|c|c|c|c|c|c|}
\hline \multirow[b]{2}{*}{ Variable } & \multicolumn{2}{|c|}{ (1) Entire Sample } & \multicolumn{2}{|c|}{ (2) Low DOI } & \multicolumn{2}{|c|}{ (3) High DOI } \\
\hline & Mean & St.Dev. & Mean & St.Dev. & Mean & St.Dev \\
\hline (a) $\operatorname{LnNAFE_{\mathrm {j},\mathrm {t}}}$ & 2.3753 & 1.1898 & 2.4121 & 1.1417 & 2.3443 & 1.2281 \\
\hline (b) $\operatorname{LnMAFE_{\mathrm {i},\mathrm {t}}}$ & 0.0552 & 0.0855 & 0.0601 & 0.0966 & 0.0510 & 0.0746 \\
\hline$A G E_{\mathrm{j}, \mathrm{t}}$ & 56.3966 & 6.8126 & 55.8566 & 6.6231 & 56.8501 & 6.9365 \\
\hline$D U A L I T Y_{\mathrm{i}, \mathrm{t}}$ & 0.7781 & 0.4155 & 0.7961 & 0.4030 & 0.7631 & 0.4253 \\
\hline EXTERNAL $L_{\mathrm{i}, \mathrm{t}}$ & 0.0363 & 0.1871 & 0.0330 & 0.1787 & 0.0391 & 0.1938 \\
\hline$F O R C E D_{\mathrm{i}, \mathrm{t}}$ & 0.0465 & 0.2107 & 0.0360 & 0.1862 & 0.0554 & 0.2288 \\
\hline$I_{N T E R N A L_{\mathrm{i}, \mathrm{t}}}$ & 0.1276 & 0.3337 & 0.1227 & 0.3281 & 0.1318 & 0.3383 \\
\hline (a) LAGLnMAFE $E_{j, t-1}$ & 2.3641 & 1.1900 & 2.4076 & 1.1437 & 2.3275 & 1.2265 \\
\hline (b) LAGLnNAFE & 0.0536 & 0.0832 & 0.0592 & 0.0960 & 0.0490 & 0.0704 \\
\hline $\operatorname{LnDOI}_{\mathrm{j}, \mathrm{t}}$ & 0.6223 & 0.4609 & 0.1961 & 0.2170 & 0.9802 & 0.2659 \\
\hline$N U M_{\mathrm{i}, \mathrm{t}}:$ & 15.0247 & 8.1073 & 13.6730 & 7.4331 & 16.1599 & 8.4691 \\
\hline$P R E 4_{j, t}$ & 0.0429 & 0.2026 & 0.0410 & 0.1984 & 0.0444 & 0.2060 \\
\hline$P R E 3_{j, t}$ & 0.0425 & 0.2017 & 0.0398 & 0.1954 & 0.0448 & 0.2068 \\
\hline$P R E 2_{\mathrm{j}, \mathrm{t}}$ & 0.0402 & 0.1964 & 0.0381 & 0.1914 & 0.0419 & 0.2004 \\
\hline$P R E 1_{\mathrm{j}, \mathrm{t}}$ & 0.0400 & 0.1959 & 0.0376 & 0.1904 & 0.0419 & 0.2004 \\
\hline $\operatorname{POST1}_{\mathrm{i}, \mathrm{t}}$ & 0.0429 & 0.2026 & 0.0398 & 0.1954 & 0.0455 & 0.2084 \\
\hline $\operatorname{POST} 2_{\mathrm{i}, \mathrm{t}}$ & 0.0425 & 0.2017 & 0.0402 & 0.1964 & 0.0444 & 0.2060 \\
\hline $\operatorname{POST}_{j, t}$ & 0.0407 & 0.1977 & 0.0385 & 0.1924 & 0.0426 & 0.2021 \\
\hline $\operatorname{POST}_{j, t}$ & 0.0386 & 0.1927 & 0.0372 & 0.1894 & 0.0398 & 0.1955 \\
\hline$R E G F D_{\mathrm{j}, \mathrm{t}}$ & 0.2524 & 0.4344 & 0.2555 & 0.4362 & 0.2497 & 0.4329 \\
\hline$S O X_{\mathrm{i}, \mathrm{t}}$ & 0.4503 & 0.4976 & 0.4585 & 0.4984 & 0.4433 & 0.4969 \\
\hline VOLUNTAR $Y_{\mathrm{i}, \mathrm{t}}$ & 0.1174 & 0.3219 & 0.1197 & 0.3247 & 0.1155 & 0.3196 \\
\hline No. observations & \multicolumn{2}{|c|}{5179} & \multicolumn{2}{|c|}{2364} & \multicolumn{2}{|c|}{2815} \\
\hline
\end{tabular}

Many of these results are discussed in the prior sections, but this table provides additional results. First, the two forecast error variables and the lagged forecast error variables indicate that forecast error for low DOI firms tends to be greater than it is for high DOI firms. Results further indicate that the normalized values are less dispersed than the non-normalized values. In general, this data may indicate that earnings for high DOI firms are more predictable than for low DOI firms. This is consistent with the research indicating that earnings are less dispersed, hence more predictable for firms with a greater level of international diversification (e.g., Hugues, Logue, \& Sweeney, 1975; Qian, 1996; Reeb, Mansi, \& Allee, 2001; Reuer et al., 2000).

Next, this study further analyzed the average forecast accuracy on a quarterly basis surrounding the turnover event. Results indicate that for both the high DOI firms and the low DOI firms, the forecast error increases significantly in the quarters leading to the turnover event. However, in the periods following the turnover event, the forecast error remains consistently high for high DOI firms, whereas the low DOI firms show a significant drop in forecast error in the second quarter following the event. The following table provides a summary of the information in the periods surrounding the turnover event. Next, the following figure below provides a different representation of the trends in both forecast accuracy variables: 
Table 3

Descriptive Statistics for Absolute Forecast Error - Entire Sample, Low DOI sample, and High DOI sample

\begin{tabular}{c|cc|cc|cc}
\hline & \multicolumn{9}{|c}{$(a)$ LnMAFE $_{\mathrm{i}, \mathrm{v}}\left((b)\right.$ LnNAFE $\left._{\mathrm{i}, \mathrm{y}}\right)$} \\
\cline { 2 - 7 } Period & \multicolumn{2}{|c|}{ (1) Entire Sample } & \multicolumn{2}{c}{$(2)$ Low DOI } & \multicolumn{2}{c}{ (3) High DOI } \\
\cline { 2 - 7 } & Mean & St.Dev. & Mean & St.Dev. & Mean & St.Dev. \\
\hline PRE4 & $0.0455(2.431)$ & $0.0538(1.165)$ & $0.0503(2.588)$ & $0.0535(1.114)$ & $0.0419(2.313)$ & $0.0540(1.194)$ \\
PRE3 & $0.0519(2.359)$ & $0.0986(1.189)$ & $0.0600(2.433)$ & $0.1365(1.221)$ & $0.0458(2.303)$ & $0.0523(1.166)$ \\
PRE2 & $0.0609(2.485)$ & $0.1105(1.274)$ & $0.0661(2.504)$ & $0.1292(1.085)$ & $0.0570(2.472)$ & $0.0945(1.403)$ \\
PRE1 & $0.0729(2.614)$ & $0.1461(1.373)$ & $0.0883(2.674)$ & $0.2000(1.293)$ & $0.0609(2.568)$ & $0.0828(1.436)$ \\
POST1 & $0.0761(2.696)$ & $0.1355(1.315)$ & $0.0776(2.671)$ & $0.1500(1.213)$ & $0.0750(2.715)$ & $0.1245(1.390)$ \\
POST2 & $0.0645(2.616)$ & $0.0986(1.347)$ & $0.0623(2.547)$ & $0.1152(1.152)$ & $0.0657(2.669)$ & $0.0841(1.480)$ \\
POST3 & $0.0684(2.572)$ & $0.1111(1.234)$ & $0.0692(2.545)$ & $0.1334(1.251)$ & $0.0679(2.591)$ & $0.0911(1.225)$ \\
POST4 & $0.0661(2.623)$ & $0.1251(1.305)$ & $0.0691(2.513)$ & $0.1721(1.232)$ & $0.0635(2.709)$ & $0.0694(1.359)$ \\
All other & $0.0522(2.302)$ & $0.0721(1.141)$ & $0.0577(2.343)$ & $0.0754(1.118)$ & $0.0474(2.259)$ & $0.0689(1.167)$
\end{tabular}

Figure 1

Comparative Charts for Absolute Forecast Error Variables LnMAFE \& LnNAFE.
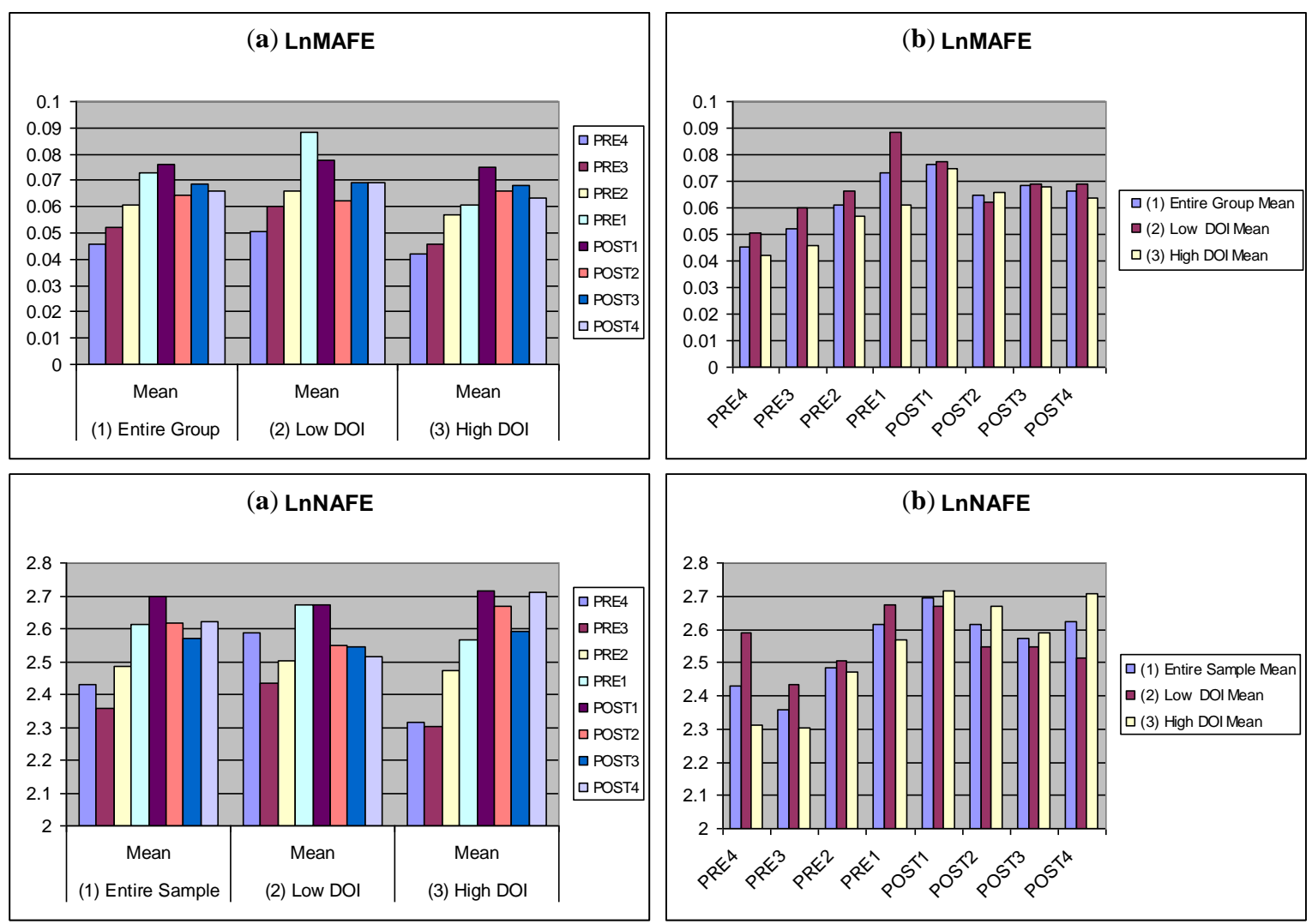

An examination of these charts, along with the preceding table provides a preliminary observation of the change in forecast accuracy during the periods surrounding the turnover period. In general, the charts provide evidence of an upward trend in the forecast error during the periods leading up to the turnover event, followed by a decreasing trend during the periods following the turnover event. For low DOI firms, the period with the greater forecast error is the quarter before the turnover event. These results further indicate that the forecast accuracy continues to degrade for another quarter for high DOI firms, whereas the accuracy tends to remain stable for low 
DOI firms, and even improves for $L n M A F E_{\mathrm{j}, \mathrm{t}}$ in periods following the PRE1 period. During the post-turnover period, results for $L n M A F E_{\mathrm{j}, \mathrm{t}}$ indicate that the forecast error temporarily decreases for high DOI firms for two quarters, but increases once again during the POST4 period. The trend for low DOI firms is generally downward during the postturnover periods. Hence, before controlling for different factors that may impact forecast accuracy, there is an evident difference in the forecast error trend between the different DOI categories. These results indicate that in general, across the entire sample, the forecast error is at its worst during the periods surrounding the turnover event, but tends to stabilize during subsequent periods. Results from the different DOI categories suggest that the forecast error decreases at a faster rate for low DOI firms than for high DOI firms. The following section provides a further investigation into these results.

\subsection{Regression Results}

The following tables provide the regression results for the entire sample, along with the regression results reflecting the different levels of firm DOI. The regressions results are presented for both (a) $L n M A F E_{\mathrm{j}, \mathrm{t}}$ and $(b)$ $L n M A F E_{\mathrm{j}, \mathrm{t}}$. The results highlight the significant regression coefficients that were included in the stepwise regression analysis and indicate $p$-values that are within the $10 \%, 5 \%$, or $1 \%$ level of significance. These results are used to further analyze $\mathrm{H} 1-\mathrm{H} 4$.

Table 4

Summary Regression (a) Results - Impact of DOI on the Relationship between (a) LnMAFE $\mathrm{L}_{\mathrm{j}, \mathrm{t}}$ and CEO Turnover Events

\begin{tabular}{|c|c|c|c|}
\hline & \multicolumn{3}{|c|}{ 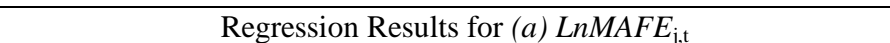 } \\
\hline Independent Variable & (1) Entire Sample & (2) Low DOI & (3) High DOI \\
\hline$A G E_{\mathrm{i}, \mathrm{t}}$ & 0.012 & 0.009 & 0.017 \\
\hline DUALITY $Y_{\mathrm{i}, \mathrm{t}}$ & 0.015 & 0.033* & 0.011 \\
\hline EXTERNAL $L_{\mathrm{j}, \mathrm{t}}$ & 0.017 & $0.037 * *$ & -0.000 \\
\hline FORCED $D_{\mathrm{i}, \mathrm{t}}$ & $\mathbf{0 . 0 5 3}^{* * *}$ & $0.056 * * *$ & $\mathbf{0 . 0 3 2} * *$ \\
\hline INTERNAL $_{\mathrm{i}, \mathrm{t}}$ & 0.000 & -0.010 & 0.005 \\
\hline$L A G L n A F E_{j, t-1}$ & $0.572 * * *$ & $0.548 * * *$ & $0.590 * * *$ \\
\hline$L n D O I_{\mathrm{j}, \mathrm{t}}$ & $-0.025 * *$ & $-0.042 * *$ & -0.010 \\
\hline$N U M_{\mathrm{i}, \mathrm{t}}:$ & $-0.028 * *$ & $-0.051 * * *$ & -0.010 \\
\hline PRE4 $_{i, t}$ & -0.013 & -0.009 & -0.010 \\
\hline$P R E 3_{i, t}$ & 0.009 & 0.018 & 0.004 \\
\hline$P R E 2_{\mathrm{i}, \mathrm{t}}$ & 0.012 & 0.000 & $0.027 *$ \\
\hline$P R E 1_{\mathrm{i}, \mathrm{t}}^{1, \mathrm{t}}$ & $\mathbf{0 . 0 3 5 * * *}$ & $0.056 * * *$ & 0.017 \\
\hline$P O S T 1_{\mathrm{i}, \mathrm{t}}$ & 0.012 & -0.013 & $\mathbf{0 . 0 3 7} * *$ \\
\hline$P O S T 2_{\mathrm{i}, \mathrm{t}}$ & $-0.025 * *$ & $-0.041 * *$ & -0.000 \\
\hline POST3 $3_{j, t}$ & 0.012 & 0.012 & 0.014 \\
\hline POST4 $_{j, t}$ & -0.010 & -0.011 & -0.010 \\
\hline$R E G F D_{\mathrm{i}, \mathrm{t}}$ & $0.041 * * *$ & 0.038* & $0.042 * *$ \\
\hline 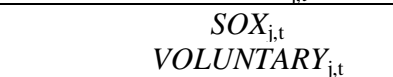 & $\begin{array}{c}\mathbf{0 . 0 8 5}^{* * * *} \\
0.010\end{array}$ & $\begin{array}{c}\mathbf{0 . 0 9 9} * * * * \\
-0.010\end{array}$ & $\begin{array}{c}\mathbf{0 . 0 7 5} * * * \\
0.004\end{array}$ \\
\hline \multicolumn{4}{|c|}{ p-value: $*<0.10, * *<0.05, * * *<0.01$} \\
\hline F Score $($ Prob > F) & $365.061(0.000)$ & $131.263(0.000)$ & $278.542(0.000)$ \\
\hline $\mathrm{R}^{2}\left(\right.$ Adjusted $\mathrm{R}^{2}$ ) & $0.361(0.360)$ & $0.357(0.355)$ & $0.373(0.372)$ \\
\hline Durbin Watson & 2.17 & 2.14 & 2.12 \\
\hline
\end{tabular}


Table 5

Summary Regression (b) Results - Impact of DOI on the Relationship between (b) LnNAFE , $_{\mathrm{j}, \mathrm{t}}$ and CEO Turnover Events

\begin{tabular}{|c|c|c|c|}
\hline & \multicolumn{3}{|c|}{ 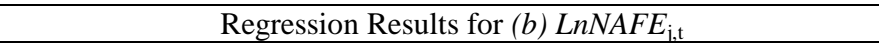 } \\
\hline Independent Variable & (1) Entire Sample & (2) Low DOI & (3) High DOI \\
\hline$A G E_{\mathrm{j}, \mathrm{t}}$ & 0.001 & -0.008 & 0.014 \\
\hline$D U A L I T Y_{\mathrm{i}, \mathrm{t}}$ & -0.002 & 0.020 & -0.018 \\
\hline EXTERNAL $L_{\mathrm{i}, \mathrm{t}}$ & 0.012 & $0.040 * *$ & 0.002 \\
\hline FORCED $D_{\mathrm{i}, \mathrm{t}}$ & $0.025 * *$ & 0.020 & 0.020 \\
\hline INTERNAL $L_{\mathrm{i}, \mathrm{t}}$ & -0.001 & 0.000 & 0.011 \\
\hline$L A G L n A F E_{j, t-1}$ & $0.673 * * *$ & $0.648 * * *$ & $0.693 * * *$ \\
\hline $\operatorname{LnDOI}_{\mathrm{j}, \mathrm{t}}$ & -0.009 & $-0.027 *$ & 0.013 \\
\hline$N U M_{\mathrm{i}, \mathrm{t}}:$ & 0.016 & 0.021 & 0.016 \\
\hline$P_{R E 4}{ }_{j, t}$ & 0.012 & 0.008 & 0.018 \\
\hline$P R E 3_{j, t}$ & -0.006 & -0.013 & 0.002 \\
\hline$P R E 2_{\mathrm{i}, \mathrm{t}}$ & $0.019 *$ & 0.010 & $0.028 * *$ \\
\hline$P R E 1_{\mathrm{j}, \mathrm{t}}^{1, \mathrm{t}}$ & $0.29 * * *$ & $0.037 * *$ & $0.024 *$ \\
\hline $\operatorname{POST1}_{\mathrm{i}, \mathrm{t}}$ & $0.022 * *$ & 0.018 & $0.030 * *$ \\
\hline $\operatorname{POST} 2_{\mathrm{i}, \mathrm{t}}$ & -0.002 & -0.017 & 0.015 \\
\hline $\operatorname{POST}_{j, t}$ & 0.004 & 0.007 & 0.006 \\
\hline $\mathrm{POST}_{j, t}$ & 0.011 & -0.007 & $0.027 * *$ \\
\hline$R E G F D_{\mathrm{j}, \mathrm{t}}$ & $0.045 * * *$ & 0.015 & $0.064 * * *$ \\
\hline$S O X_{\mathrm{j}, \mathrm{t}}$ & $0.036 * * *$ & $0.029 *$ & $0.033 * * *$ \\
\hline VOLUNTARY $Y_{\mathrm{i}, \mathrm{t}}$ & 0.006 & -0.012 & -0.004 \\
\hline \multicolumn{4}{|c|}{ p-value: $*<0.10, * *<0.05, * * *<0.01$} \\
\hline F Score $($ Prob $>$ F) & $575.355(000)$ & $364.378(0.000)$ & $398.141(0.000)$ \\
\hline $\mathrm{R}^{2}\left(\right.$ Adjusted $\mathrm{R}^{2}$ ) & $0.471(0.470)$ & $0.436(0.435)$ & $0.498(0.497)$ \\
\hline Durbin Watson & 2.23 & 2.21 & 2.23 \\
\hline
\end{tabular}

First, $\mathrm{H} 1$ and $\mathrm{H} 2$ were assessed by observing results for the entire sample in the first regression in both tables above, along with the previous general results describing the mean values for LnMAFE and LnNAFE during the pre-turnover and post-turnover periods. The null hypothesis for $\mathrm{H} 1$ indicates that "CEO turnover events do not have a negative impact on analyst forecasting accuracy during pre-turnover periods". After controlling for the different turnover criteria, along with other important control variables, results indicate that the variable $P R E 1_{\mathrm{j}, \mathrm{t}}$ has a significant and positive impact on forecast error for both regressions (a) and (b). Hence, the null hypothesis for H1 can be rejected. The null hypothesis for $\mathrm{H} 2$ indicates that "CEO turnover events do not have a positive impact on analyst forecasting accuracy during post-turnover periods". The statistical results for (a) indicate that the forecast error typically decreases during the post-turnover periods. Regression (a) results further indicate that the POST2 period has a negative and significant impact on forecast error. Although the POST1 period has a positive impact on forecast error, this period includes the turnover event itself, which may occur at the beginning or at the end of the quarter, and should therefore not be considered in assessing hypothesis results. However, the significant negative impact of the POST2 dummy variable in the regression (a) is not consistent with the results for regression (b), and the insignificance of other variables in the post-turnover periods for both regressions, therefore, the null hypothesis for $\mathrm{H} 2$ cannot be rejected.

Next, H3 and H4 were assessed by further observing the results for the low DOI and the high DOI categories in both regressions (a) and (b). The null hypothesis for $\mathrm{H} 3$ indicates that "A higher degree of internationalization in the covered firm does not lead to a decrease in the accuracy of analyst forecasts during preturnover periods". The results indicate that the forecast error increases for both low DOI and high DOI firms during the pre-turnover periods. Results further indicate that the increase in forecast error is more significant for low DOI firms during the PRE1 period, but a larger number of variables are positive and significant for the high DOI firm category. Hence, given these extent of these mixed results, the null hypothesis for $\mathrm{H} 3$ cannot be rejected. Although $\mathrm{H} 3$ cannot be rejected, these results are interesting nonetheless, given the distribution of inaccurate pre-turnover periods for low DOI versus high DOI firms. In general, both groups experience an increase in forecast error leading up to the turnover event. However, the negative impact on forecast accuracy tends to begin much sooner for high 
DOI firms than they do for low DOI firms. The results also suggest that company stakeholders for high DOI firms are more tolerant of the management teams decreased level of transparency or that the complexity of such firms lends itself to limit their disclosures to the investment community for a longer period of time in comparison with low DOI firms.

Next, the null hypothesis for $\mathrm{H} 4$ indicates that "A higher degree of internationalization in the covered stock does not lead to a decrease in the accuracy of analyst forecasts during post-turnover periods". Results for the postturnover periods indicate that the variables POST1 and POST4 have a positive and significant impact on forecast error for high DOI firms. However, these results are not observed for low DOI firms. Results for the low DOI group indicate that after controlling for important variables, the impact of the post-turnover variables is insignificant in almost all cases, except for the POST2 variable in regression (a), which actually results in a significant decrease in the forecast error variable $L n M A F E_{\mathrm{j}, \mathrm{t}}$. Overall, results indicate that the fourth hypothesis, $\mathrm{H} 4$ can be rejected. Results suggest that turnover events tend to negatively affect the forecasting accuracy of firms with higher levels of DOI, or firm complexity, and that the accuracy for low DOI firms tends to converge to historical levels significantly faster during the post-turnover period.

The analysis of all other turnover variables is equally interesting in this study. The results indicate that in general, voluntary turnovers do not lead to an increase in forecast accuracy in any case. However, forced turnovers typically lead to a decrease in mean absolute forecast error across all three groups, and the negative impact on accuracy is greater for low DOI firms than it is for high DOI firms. Results for regression (b) show similar results in the entire sample category. This data suggests that the type of turnover has limited impact on the normalized forecast error, but has a general impact on the mean absolute forecast error. Next, the impact of internal successions was found to have no impact on accuracy, yet the impact of external successions only has a positive impact on forecast error for low DOI firms in both regressions. This result may indicate that the amount of information communicated by the new successor is limited due to their unfamiliarity with the firm or their conservative nature in releasing information that may improve the firm's transparency. Alternatively, the decrease in forecast accuracy can be due to the analysts' unfamiliarity with the new CEO.

Results for the other two executive control variables indicate that age is not a significant factor and duality only has a limited negative impact on accuracy for low DOI firms. This result suggests that forecasts are less accurate for domestically oriented firms with CEOs who are also chairman of the board. Hence, CEOs with less risk of losing their job may feel less threatened or may be less willing to provide guidance or improve their firm's transparency with-respect-to the investment community.

Firm results for DOI also play a significant role in the two regressions. The control variable LnDOI has a positive and significant impact on the accuracy for low DOI firms, but results indicate no significant impact for high DOI firms. This result suggests that there is a range in which incremental firm DOI plays a significant role in forecasting results, but beyond that range, the incremental DOI plays less of a role in being able to accurately forecast results. Low DOI firms have a lower number of segments, international sales, or assets. Therefore, when companies communicate information about such segments, it typically helps reveals more information about their domestics segments, and therefore helps improves overall forecasts. Results indicate that this phenomenon does not occur for the high DOI group, which suggests that such firms are more complex to analyze than low DOI firms.

The Regulatory periods also play a role in being able to accurately forecast results for a given firm. Results indicate that the impact of RegFD has a greater significance and less of a negative impact on forecast accuracy for high DOI firms than it does for low DOI firms. Results further indicate that the SOX period had a negative impact on accuracy for both low DOI firms and high DOI firms, but results are mixed regarding the strength of the impacts in either category. This may indicate that the quantity or quality of information flowing between executive management and analysts has decreased during these two regulatory periods, leading to an increase in the complexity of analysis.

Finally, the control variables for analyst characteristics provided significant relationships. First, consistent with prior research, the lagged forecast accuracy has been found to play a significant role for both low DOI and high 
DOI groups. Hence, the current forecast error is positively related to the previous forecast error. This is an important variable as it strengthens the results for the post-turnover and pre-turnover periods. Next, results indicate that the number of analyst following a given firm only plays a significant role for the entire sample and for low DOI firms. This indicates that the number of analysts collecting information for low DOI firms plays a significant role in being able to reveal data about those firms, and therefore increase the accuracy. As described in the previous section, the average number of analysts covering low DOI firms is significantly less than the number of analysts covering high DOI firms. As described in the previous section, the increase in the number of analysts in the post turnover period is greater for low DOI firms than for high DOI firms. Results differ for high DOI firms and indicate that the number of analysts plays no significant role in that category.

All regressions were performed using stepwise regression. The low value for the Durbin Watson statistic in both cases further indicates that there is limited negative serial correlation in the results. The correlation analysis among significant variables indicates that a low or insignificant correlation exists among most independent variables. The exceptions include a high negative correlation in the RegFD and SOX periods (-0.52, $1 \%$ level of significance), as well as a high correlation between the external successor variable and the forced turnover variable $(0.35,1 \%$ level of sig. for the entire sample, and $0.41,1 \%$ level of sig. for the high DOI group, and $0.26,1 \%$ level of sig. for low DOI firms). In separate tests, results remained relatively consistent when removing the RegFD variable, and the external successor variables. In all cases, regression residuals followed a relatively normal distribution, with a mean or expected value approximately equal to zero.

\section{Conclusion}

In summary, this study investigated the impact of CEO turnover events on the accuracy of analyst forecasts. In particular, the impact of the turnover event has been examined for firms with different levels of internationalization, a proxy for firm complexity. The literature has shown that the accuracy of analyst forecasts tends to decrease as the complexity of the firm increase. Other research has shown that the amount of information becoming available around CEO turnover events can help improve the transparency of the given firm. This study extends prior literature by showing the link between these two branches of research. After controlling for specific firm, analyst, and turnover variables, results indicate that the level of accuracy tends to decrease during the periods leading up to the turnover event and the level of forecast error tends to decrease during periods following the turnover event. Results indicate that the forecast accuracy tends to decrease during the post-turnover periods for high DOI firms whereas the accuracy tends to increase for low DOI firms during the post turnover periods. Hence, results suggest that different trends manifest themselves during the post-turnover periods for the different DOI categories.

Results for the pre-turnover periods indicate that all groups suffer a decrease in forecast accuracy for the periods preceding the turnover event. Results further suggest that the forecast accuracy tends to decrease for extended periods within the high DOI category, but tends to be less excessive than the shortened but increased level of negative impact realized for the low DOI category.

Overall, the results from this study suggest that the level of information communicated to the investment community has a significant role in allowing analysts and investors to paint an accurate state about the state of the company and their earnings. Specifically, results suggest that information and firm transparency decreases during the periods leading up to the turnover event. When the company announced the turnover event, transparency tends to improve, hence forecast accuracy tends to improve. However, the level of information tends to have a greater impact in improving forecasts for low DOI firms than it does for high DOI firms. In general, results indicate the level of DOI is an important factor when analyzing firms during CEO turnover events.

This study provides a better understanding of the link between information disclosure and the complexity of the forecast task. Areas for future research study may include a more detailed analysis of firms with multiple levels of DOI, a more detailed analysis of different periods, including days, weeks, months, and even years surrounding the turnover event, and to further understand the impacts of other relevant firm and analyst characteristic factors. Other areas might include similar analyses of non-U.S.-based firms and analysts. 


\section{Bibliography}

1. Abdelghany, K.E. (2005). Measuring the quality of earnings. Managerial Auditing Journal. 20(9), 10011015.

2. Aggarwal, R., \& Williamson, R. (2006). Did new regulations target the relevant corporate governance attributes? Paper presented at the Financial Management Association Conference, Salt Lake City, UT.

3. Ashbaugh, H., \& Pincus, M. (2001). Domestic accounting standards, international accounting standards, and the predictability of earnings. Journal of Accounting Research, 39, 417-434.

4. Bailey, W., Li, H., Mao, C., \& Zhong, R. (2003). "Regulation Fair Disclosure and earnings information: Market analyst, and corporate responses." Journal of Finance. 58(6), 2487-2514.

5. Balakrishnan, R., Harris, T., \& Sen, P. (1990). The predictive ability of geographic segment disclosures. Journal of Accounting Research, 28, 305-325.

6. Baldwin, B. (1984). Segment earnings disclosure and ability of security analysts to forecast earnings per share. The Accounting Review, 59, 376-389.

7. Beim, D.O., \& Calomiris, C.W. (2001). Emerging financial markets. New York: McGraw-Hill.

8. Bernard, M. R. (2008). The impact of education, regulation, and internationalization on the accuracy of analyst forecasts. Dissertation Draft, Nova Southeastern University.

9. Bernstein, E.S., (2006). All's Fair in Love, War \& Bankruptcy? Corporate Governance Implications of CEO Turnover in Financial Distress. Stanford Journal of Law, Business \& Finance, 11(2), 299-325.

10. Bhushan, R. (1989). Firm characteristics and analyst following. Journal of Accounting and Economics, 11, 255-274.

11. Blackwell, D.W., \& Dudney, D.M. Farrell, K. (2007). Changes in CEO compensation structure and the impact on firm performance following CEO turnover. Review of Quantitative Finance and Accounting, 29(3) 315-338.

12. Bonner, S.E. (1994). A model of the effects of audit task complexity. Accounting, Organizations and Society, 19(3), 213-234.

13. Brickley JA, Coles JL, Jarrell G. 1997. Leadership structure: separating the CEO and Chairman of the Board. Journal of Corporate Finance, 3, 189-220.

14. Brockman, C.M., \& Brooks, R. (1998, Nov/Dec) The CFA Charter: Adding Value to the Market. Financial Analysts Journal. 54 (6), 81.

15. Brown, L.D. (2001). How important is past analyst forecast accuracy? Financial Analysts Journal, 57(6), 44-49.

16. Brown, L., Griffin, P., Hagerman R., \& Zmijeski, M. (1987). Security Analyst Superiority Relative to Univariate Time-Series Models in Forecasting Quarterly Earnings. Journal of Acounting and Economics, 11, 61-87.

17. Brown, L.D. (1993). Earnings forecasting research: Its implications for capital market research. International Journal of Forecasting, 9, 295-320.

18. Brown, L.D., \& Rozeff, M.S., (1980) Analysts Can Forecast Accurately, Journal of Portfolio Management, 6, 31-34.

19. Brown, P., Foster, G., \& Noreen, E. (1985). Security analyst multi-year earnings forecasts and the capital markets. Studies in Accounting Research, American Accounting Association, 21.

20. Bunn, D., \& Wright, G. (1991). Interaction of judgmental and statistical forecasting methods: issues and analysis. Management Science, 27, 501-518.

21. Butler, K., \& Lang, L. (1991). The forecast accuracy of individual analysts: evidence of systematic optimism and pessimism. Journal of Accounting Research, 29, 150-56.

22. Chansog, K., \& Pantzalis, C. (2003). Global/ndustrial diversification and analyst herding. Financial Analysts Journal, 59(2), 14-15.

23. Clayton, C., Hartzell, C., \& Rosenberg, J. (2005). The impact of CEO turnover on equity volatility. The Journal of Business, 78 (5), 1779.

24. Clement, M.B. (1999). Analyst forecast accuracy: Do ability, resources, and portfolio complexity matter? Journal of Accounting and Economics, 21, 285-303.

25. Clement, M.B., \& Tse, S.Y. (2003). Do investors respond to analysts' forecast revisions as if forecast accuracy is all that matters? The Accounting Review, 78(1), 227-250. 
26. Collins, D. (1976). Predicting earnings with subentity data: Some further evidence. Journal of Accounting Research, 14, 163-177.

27. Conyon, M. and A. Florou, 2002, Top executive dismissal, ownership and corporate performance. Accounting and Business Research, 32, 209-225.

28. Coughlan, A. \& Schmidt, R. (1985). Executive compensation, management turnover and firm performance: An empirical investigation. Journal of Accounting and Economics, 7, 43-66.

29. Cox, R.A.J, \& Kleiman, R.T., (2002). Superstardom and institutional investor's all-British research team. Managerial Finance, 28(1), 1-13.

30. Dahya, J., Lonie, A., \& Power, D. (1998). Ownership structure, firm performance and top executive change: An analysis of UK firms. Journal of Business Finance and Accounting, 25, 1089-1118.

31. Dahya, J., McConnell, J.J., \& Travlos, N.G. (2002). The Cadbury committee, corporate performance and top management turnover. Journal of Finance, 57, 461-483.

32. Das, S. \& Saudagaran, S. (1998). Accuracy, bias, and dispersion in analysts' earnings forecasts: The case of cross-listed foreign firms. Journal of International Financial Management and Accounting, 9, 16-33.

33. Das, S. \& Saudagaran, S. (2002). Accuracy of analysts' earnings forecasts: A comparison of non-U.S. cross-listed firms and U.S. multinationals. Journal of International Accounting Research, 1, 61-74.

34. Das, S., Levine, C., \& Sivaramakrishnan, K. (1998). Earnings predictability and bias in analysts' earnings forecasts. The Accounting Review, 73, 277-294.

35. Dedman, E. \& S.W.J. Lin, 2002, Shareholder wealth effects of CEO departures: evidence from the UK. Journal of Corporate Finance, 8, 81-104.

36. Denis, J. \& Denis, D.K. (1995). Performance changes following top management dismissals. Journal of Finance, 50, 1029-1057.

37. Denis, J., Denis, D.K., \& Sarin, (1997). Ownership structure and top executive turnover. Journal of Financial Economics, 45, 193-221.

38. Denis, J., Denis, D.K., \& Yost, K. (2002). Global diversification, industrial diversification, and firm value. Journal of Finance, 57(5), 1951-1979.

39. Diamonte, R.L., Liew, J.M., \& Stevens, R.S. (1996). Political risk in emerging and developed markets. Financial Analysts Journal 52 (3), 71-76.

40. Dunn, K., Nathan, S. (2005). Analyst industry diversification and earnings forecast accuracy. Journal of Investing, 14(2), 7-14.

41. Dunning, J.H., \& Rugman, A. (1985). The influence of Hymer's dissertation on theories of foreign direct investment. American Economic Review, 75, 228-232.

42. Duru, A., \& Reeb, D.M. (2002). International diversification and analysts' forecast accuracy and bias. The Accounting Review, 77(2), 415-433.

43. Erwin, G.R., \& Perry, S.E. (2000). The effect of foreign diversification on analysts' prediction errors. International Review of Financial Analysis, 9, 121-145.

44. Fama, E.F. \& Jensen, M.C. (1983). Separation of ownership and control. Journal of Law and Economics, $88,301-325$.

45. Findlay, S., \& Mathew, P.G. (2006). An examination of the differential impact of Regulation FD on analysts' forecast accuracy. Financial Review, 41(1), 9-31.

46. Forbes, W., Huijgen, C., \& Plantinga, A. (2006). Using analysts' earnings forecasts for country/industrybased asset allocation. Managerial Finance, 32(4), 317-337.

47. Fortin, R., \& Michelson, S. (2006). The earnings forecast accuracy of financial analysts who are CFA charterholders. Journal of Investing, 15(3), 19-24.

48. Gaines-Ross, L (2002). CEOs stranded in wonderland. The Journal of Business Strategy, 23 (2), 18.

49. Gietzmann, M.B., \& Trombetta, M. (2001). Disclosure interactions: Accounting policy choice and voluntary disclosure effects on the cost of capital. Working paper, University of Bristol, Bristol, UK., and Carlos III University, Madrid, Spain.

50. Gilson, S.L. (1989). Management turnover and financial distress. Journal of Financial Economics, 25, $241-$ 262.

51. Gomes, A., Gorton, G., \& Madureira, L. (2004). SEC Regulation Fair Disclosure, information, and the cost of capital. Working Paper, University of Pennsylvania, Philadelphia, PA. 
52. Haddadj, S. (1999), CEO succession and strategic change and orientation in small and medium sized firms: new perspectives from France, The Journal of Applied Business Research, 15, 81-97.

53. Hadlock, C.J., Lee, D.S., \& Parrino. R. (2002). Chief executive officer careers in regulated environments: Evidence from electric and gas utilities. Journal of Law and Economics, 45(2:1), 535-563.

54. Harrison, J.R., Torres, D.L., \& Kukalis, S. (1988). The changing of the guard: turnover and structural change in the top-management. Administrative Science Quarterly, 33 (2), 211.

55. Haw, I., Jung, K., \& Ruland, W. (1994). The accuracy of financial analysts forecasts after mergers. Journal of Accounting, Auditing and Finance, 9, 465-486.

56. Herrmann, D. \& Thomas, W. B. (2005). Rounding of analyst forecasts. The Accounting Review, 80(3), 805824.

57. Hillier, D., Marshall, A., McColgan, P., \& Werema, S. (2006). Company performance surrounding CEO turnover: evidence from the UK, Working Paper, European Financial Management Association. Retrieved August 1, 2006, from EFMA site: http://www.efmaefm.org/efma2006/papers/368955 full.pdf

58. Hope, O-K. (2003). Accounting policy disclosures and analysts' forecasts. Contemporary Accounting Research, 20, 295-321.

59. Hope, O-K., Kang, T. (2005). The association between macroeconomic uncertainty and analysts' forecast accuracy. Journal of International Accounting Research, 4(1), 23-39.

60. Hsu, D., Chiao, M. (2006). Persistence of analysts' performance in earnings forecasts. Paper presented at the Financial Management Association Conference, Salt Lake City, UT.

61. Huang, W.C., \& Yen, G. (1996). The impact of proxy contests on managerial turnover: A test of the job security. Managerial and Decision Economics, 17(6), 551.

62. Huson, M., Malatesta, P. \& Parrino, R. (2004). Managerial succession and firm performance', Journal of Financial Economics, Vol. 74, pp. 237-275.

63. Huson, M., Parrino R., \& Starks, L.T. (2001). Internal monitoring and CEO turnover: A long-term perspective. Journal of Finance, 56, 2265-2297.

64. Irani, A.J. \& Karamanou, I. (2003). Regulation fair disclosure, analyst following, and analyst forecast dispersion. Accounting Horizons, 17(1), 15-29.

65. Jacob, J, Lys, T., \& Neale, M. (1999). Expertise in forecasting performance of security analysts. Journal of Accounting and Economics 28 (1), 27-50.

66. Jensen M, \& Murphy K. (1990). Performance pay and top management incentives. Journal of Political Economy, 98, 225-264.

67. Kahneman, D. (1973). Attention and effort. Englewood cliffs, NJ: Prentice-Hall.

68. Kang, J. and A. Shivdasani, 1995, 'Firm performance, corporate governance, and top executive turnover in Japan', Journal of Financial Economics, Vol. 38, pp. 29-58.

69. Kelly, K. (2007). Roller coaster leadership. Business Strategy Review, 18(1), 22.

70. Khanna, N. and A.B. Poulsen, 1995, 'Managers of financially distressed firms: Villains or scapegoats?', Journal of Finance, 50, 919-940.

71. Khurana, I., Pereira, R., Raman, K. (2003). Does analyst behavior explain market mispricing of foreign earnings for U.S. multinational firms? Journal of Accounting, Auditing \& Finance, 18(4), 453-477.

72. Kim, C.W., Hwang, P. \& Burgers, W.P. (1993). Multinationals' Diversification and the Risk Return TradeOff. Strategic Management Journal, 14, 275-286.

73. Koh, K., Matsumoto, D., \& Rajgopal, S. (2005). Meeting or beating analysts' expectations in the post-SOX world: Changes in stock market rewards and managerial actions. Working paper, University of Washington, Seattle, WA.

74. Kwag, S., \& Small, K. (2007). The impact of regulation fair disclosure on earnings management and analyst forecast bias. Journal of Economics and Finance, 31(1), p. 87.

75. Lang, M., Lins, K.V., \& Miller, D. (2003). ADRs, analysts, and accuracy: Does cross-listing in the U.S. improve a firm's information environment and increase firm value? Journal of Accounting Research, 41(3), 317-345.

76. Lang, M., \& Lundholm, R. (1996). Corporate disclosure policy and analyst behavior. The Accounting Review, 71, 467-492.

77. Lim, T. (2001). Rationality and analysts' forecast bias. Journal of Finance, 56 (1), 369-385. 
78. Loh, R.K., \& Mian, M.G. (2006). Do accurate earnings forecasts facilitate superior investment recommendations? Journal of Financial Economics, 80(2), 455.

79. Lucier, C., Spiegel, E., Schuyt, R., (2002) Why CEOs Fall: The Causes and Consequences of Turnover at the Top, Strategy-Business. Retrieved on September 1, 2007 from Strategy-Business site: http://www.strategy-business.com/press/16635507/20306

80. Mehran, H., and D. Yermack, 1997. Stock-based compensation and top management turnover, Working paper, New York University

81. Mensah, M., Nguyen, H., \& Prattipati, S. (2006). Transparency in financial statements: A conceptual framework from a user perspective. The Journal of American Academy of Business, 9(1), 47-51.

82. Mikhail, M., \& Willis, R. (2003). Security analyst experience and post-earnings-announcement drift. The Journal of Accounting, Auditing and Finance, 18(4), 529-550.

83. Morck, R., \& Yeung, B. (1991). Why investors value multinationality. Journal of Business, 64(2), $165-87$.

84. Murphy, K.J. \& Zimmerman, J.L. (1993). Journal of Accounting \& Economics, 16(1-3), 273-305.

85. Neumann, R, \& Voetmann T. (2005) Top executive turnovers: Separating decision and control rights. Managerial and Decision Economics, 26(1), 25-37.

86. Nichols, D., Tunnel, L., \& Seipel, C. (1995). Earnings forecast accuracy and geographic segment disclosures. Journal of International Accounting, Auditing and Taxation, 8, 113-126.

87. O'Brien, P (1990), Forecast Accuracy of Individual Analysts in Nine Countries, Journal of Accounting Research, 28, 286-304.

88. O'Brien, P. (1987) Individual Forecasting Ability, Managerial Finance, 13, 3-9.

89. Paladino, B. (2007). 5 key principles of corporate performance management. Strategic Finance, 88(12), 3945.

90. Parrino R. 1997. CEO turnover and outside succession: a ross sectional analysis. Journal of Financial Economics, 46, 65-197.

91. Parson Consulting. (2005). Percentage of firms missing EPS forecast by $10 \%$ hits 18 -month low parson consulting study suggests Sarbanes-Oxley improving projections. Retrieved June 30, 2006, from Parson Consulting Web site: http://www.parsonconsulting.com/Default.aspx?id=213135\&year=2005.

92. Persons, O.S. (2006). The effects of fraud and lawsuit revelation on U.S. executive turnover and compensation. Journal of Business Ethics, 64, 405-419.

93. Puffer, S.M., \& Weintrop, J.B. (1991). Corporate performance and CEO turnover: The role of performance expectations. Administrative Science Quarterly, 36(1), 1.

94. Qian, G. (1996). The effect of multinationality measures upon the risk-return performance of US firms. International Business Review, 4, 47-265.

95. Radler, M. (2003). A brief stay at the top. Oil \& Gas Journal, 101(4), 15.

96. Reeb, D.M., Mansi, S.A., Allee, J.M. (2001). Firm internationalization and the cost of debt financing: Evidence from non-provisional publicly traded debt. Journal of Financial \& Quantitative Analysis, 36(3), 395-414.

97. Reuer, J.J. \& Leiblein, M.J. (2000). Downside risk implications of multinationality and international joint ventures. Academy of Management Journal, 43(2), 203-214.

98. Riahi-Belkaoui, A., \& Alvertos, D.K. (1998). The effects of country return and risk differences on prediction performance of earnings forecasts. Managerial Finance, 24(6), 3-9.

99. Roberts, C. (1989). Forecasting earnings using geographic segment data: Some U.K. evidence. Journal of International Financial Management and Accounting, 1, 130-151.

100. Rowe, W.W., \& Davidson III, W.N., (2000). Fund Manager Succession in Closed-End Mutual Funds. The Financial Review, 35(3), 53-78.

101. Sheikholeslami, M., Wilson, M.D., \& Selin, J.R. (1998). The impact of CEO turnover on security analysts' forecast accuracy. Journal of Applied Business Research, 14(4), 71-75.

102. Simon, H.A. (1973). The Structure of III Structured Problems, Artifcial Intelligence, 181-201.

103. Sinha, P., Brown, L.D., \& Das, S. (1997). A re-examination of financial analysts' differential earnings forecast accuracy. Contemporary Accounting Research, 14, 142.

104. Stewart. , T. A. (2007). Secrets of the Workplace. Harvard Business Review, 85(5), 14.

105. Teoh, S.H., Welch, I., \& Wong, T.J. (1998a). Earnings management and the post-issue performance of seasoned equity offerings. Journal of Financial Economics, 50, 63-99. 
106. Topaloglu, S. (2002). An examination of institutional trading activity before and after Regulation FD. Working Paper, Arizona State University, Tempe AZ.

107. Tong, H. (2007). Disclosure standards and market efficiency: Evidence from analysts' forecasts. Journal of International Economics. 72(1), p. 22.

108. Warner, J.B., Watts, R.L., \& Wruck, K.H. (1988). Stock prices and top management changes. Journal of Financial Economics, 20, 461-492.

109. Weisbach, M.S. (1988). Outside directors and CEO turnover. Journal of Financial Economics, 20, 431460 .

110. Weisbach, M.S. (1995). CEO turnover and the firm's investment decisions. Journal of Financial Economics, 27, 159-188.

111. Wen, L. (2005, April). Key Executive Turnover and Operational Performance in Poorly Performing Firms. Credit \& Financial Management Review. Retrieved August 3, 2006, from Credit \& Financial Management Review site: http://www.allbusiness.com/credit-financial-management-review/20050401/3038039-1.html

112. Wiersema, M. (2002). Holes at the top: Why CEO firings backfire. Harvard Business Review, 80(12), 70.

113. Worrell, D.L, Davidson, W.N. III, and Glascock, J. L. (1993, April) Stockholder reactions to departures and appointments of key. Academy of Management Journal. 36(2), 387.

\section{NOTES}

